\title{
Rubinisphaera italica sp. nov. isolated from a hydrothermal area in the Tyrrhenian Sea close to the volcanic island Panarea
}

\author{
Nicolai Kallscheuer • Mareike Jogler • Sandra Wiegand • Stijn H. Peeters • \\ Anja Heuer • Christian Boedeker • Mike S. M. Jetten • Manfred Rohde • \\ Christian Jogler
}

Received: 23 June 2019/Accepted: 9 September 2019/Published online: 26 November 2019

(C) The Author(s) 2019

\begin{abstract}
Planctomycetes is a fascinating phylum of mostly aquatic bacteria, not only due to the environmental importance in global carbon and nitrogen cycles, but also because of a unique cell biology. Their lifestyle and metabolic capabilities are not well explored, which motivated us to study the role of Planctomycetes in biofilms on marine biotic surfaces. Here, we describe the novel strain Pan $54^{\mathrm{T}}$ which was isolated from algae in a hydrothermal area close to the volcanic island Panarea in the Tyrrhenian Sea, north of Sicily in Italy. The strain grew best at $\mathrm{pH} 9.0$ and $26{ }^{\circ} \mathrm{C}$ and showed typical characteristics of planctomycetal bacteria, e.g. division by polar budding, formation of aggregates and presence of stalks and crateriform structures. Phylogenetically, the strain belongs to the genus Rubinisphaera. Our analysis suggests that Pan $54^{\mathrm{T}}$ represents a novel species of this genus, for which we propose the name Rubinisphaera italica sp. nov. We suggest Pan54 ${ }^{\mathrm{T}}$ (= DSM $29369=$ LMG 29789) as the type strain of the novel species.
\end{abstract}

N. Kallscheuer · M. Jogler · S. Wiegand ·

S. H. Peeters · M. S. M. Jetten · C. Jogler $(\square)$

Department of Microbiology, Radboud Universiteit

Nijmegen, Nijmegen, The Netherlands

e-mail: christian@jogler.de

M. Jogler · A. Heuer - C. Boedeker

Leibniz Institute DSMZ, Braunschweig, Germany

M. Rohde

Central Facility for Microscopy, Helmholtz Centre for Infection Research, HZI, Braunschweig, Germany
Keywords Marine bacteria - Planctomycetes . Algae $\cdot$ Hydrothermal area $\cdot$ Panarea

\section{Introduction}

Together with Verrucomicrobia, Lentisphaerae, Kirimatiellaeota and Chlamydiae, Planctomycetes form the medically and biotechnologically relevant PVC superphylum (Spring et al. 2016; Wagner and Horn 2006; Devos and Ward 2014). In the past, Planctomycetes were postulated as the missing link between bacteria and eukaryotes (Devos and Reynaud 2010) beyond the bacterial cell plan (Devos et al. 2013; Fuerst and Sagulenko 2011). This finding was based on proposed exceptional planctomycetal features, such as, lack of peptidoglycan (König et al. 1984), a compartmentalised cell plan (Lindsay et al. 1997), a nucleus-like structure (Fuerst and Webb 1991) and performance of endocytosis (Lonhienne et al. 2010). Further investigation of the planctomycetal physiology and morphology based on the advent of novel techniques changed this picture (Jogler et al. 2011; Jogler and Jogler 2013; Rivas-Marin et al. 2016). In particular, presence of peptidoglycan in some Planctomycetes was confirmed (Jeske et al. 2015; van Teeseling et al. 2015) and thus the cell plan of Planctomycetes was reinterpreted to be Gram-negative (Boedeker et al. 2017; Devos 2014a, b). But still, Planctomycetes remain exceptional and enigmatic in 
comparison to well-characterised canonical bacteria. They e.g. divide unusually, either by budding, binary fission or even a combination of both (Wiegand et al. 2019) and lack canonical divisome proteins including the otherwise universal FtsZ (Jogler et al. 2012; Pilhofer et al. 2008).

Many Planctomycetes survive in oligotrophic environments, such as seawater, by utilising a range of highmolecular-weight sugars derived from algae (Jeske et al. 2013; Lachnit et al. 2013) after attaching to these nutrient-rich surfaces (Bengtsson et al. 2012; Bondoso et al. 2015, 2014, 2017; Lage and Bondoso 2014; Vollmers et al. 2017). In this context, a specialised morphology including the unique pili-forming crateriform structures and an extremely enlarged periplasm might be involved in the uptake and cleavage of such polymeric compounds (Boedeker et al. 2017).

It is frequently observed that Planctomycetes are highly abundant in biofilms on nutrient-rich marine surfaces (Bengtsson and Øvreås 2010; Kohn et al. 2019b). This is astonishing when considering their moderate growth rates compared to faster-growing competitors in this ecological niche (Frank et al. 2014; Wiegand et al. 2018). It is thus likely that Planctomycetes are 'talented' producers of secondary metabolites, which could mediate (symbiotic) interactions with algae or act as antibiotics (Jeske et al. 2013). Gene clusters involved in small molecule production were predicted in planctomycetal genomes, which substantiates Planctomycetes as a promising source of such bioactive compounds (Graca et al. 2016; Wiegand et al. 2019).

Taken together, Planctomycetes are amongst the most maverick of all bacteria known thus far (Wiegand et al. 2018). We are steadily aiming to expand the collection of known Planctomycetes and recently presented 79 novel strains in an overview article (Wiegand et al. 2019). Here, we introduce and validly describe Pan54 ${ }^{\mathrm{T}}$, a novel planctomycetal strain that was isolated close to the volcanic island Panarea, and describe its morphology, physiology and phylogeny. The sampling location Panarea is located in the Tyrrhenian Sea, has an area of $3.3 \mathrm{~km}^{2}$ and is the second smallest of the Aeolian islands. The island itself is only a small part of a sub-marine edifice in form of a truncated cone with an eastern protrusion with its base being $1500 \mathrm{~m}$ below sea level (Gabbianelli et al. 1990). The entire cone has a diameter of $23 \mathrm{~km}$ and an area of $460 \mathrm{~km}^{2}$ and several thermal springs are located in proximity to the island. In the surroundings of Panarea areas with increased temperatures, higher levels of nutrients including nitrogen and sulfur sources are present, which motivated us to choose this geographical location as a valuable source of so far unknown species of prokaryotes (Gugliandolo et al. 2015).

\section{Material and methods}

\section{Cultivation conditions and isolation}

For strain isolation and cultivation M1H NAG ASW medium was used. For medium preparation $0.25 \mathrm{~g}$ peptone (Bacto), $0.25 \mathrm{~g}$ yeast extract (Bacto), $2.38 \mathrm{~g}$ (4-(2-hydroxyethyl)-1-piperazineethanesulfonic acid) (HEPES) $(10 \mathrm{mM}), 250 \mathrm{~mL}$ artificial sea water (ASW) and $20 \mathrm{~mL}$ sterile-filtered Hutner's basal salt solution were mixed in a final volume of $973 \mathrm{~mL}$ double distilled water. The $\mathrm{pH}$ was adjusted to 7.5 using $5 \mathrm{M} \mathrm{KOH}$ and the solution was autoclaved for $20 \mathrm{~min}$ at $121{ }^{\circ} \mathrm{C}$. After cooling, the following solutions were added aseptically: $1 \mathrm{~mL}$ of $25 \%$ (w/v) glucose, $5 \mathrm{~mL}$ vitamin solution, $1 \mathrm{~mL}$ trace element solution and $20 \mathrm{~mL}$ of a stock solution with $50 \mathrm{~g} / \mathrm{L} \mathrm{N}$ acetyl glucosamine (NAG). ASW contained $46.94 \mathrm{~g} / \mathrm{L}$ $\mathrm{NaCl}, 7.84 \mathrm{~g} / \mathrm{L} \mathrm{Na}_{2} \mathrm{SO}_{4}, 21.28 \mathrm{~g} / \mathrm{L} \mathrm{MgCl}_{2} \times 6 \mathrm{H}_{2} \mathrm{O}$, $2.86 \mathrm{~g} / \mathrm{L} \quad \mathrm{CaCl}_{2} \times 2 \quad \mathrm{H}_{2} \mathrm{O}, \quad 0.384 \mathrm{~g} / \mathrm{L} \quad \mathrm{NaHCO}_{3}$, $1.384 \mathrm{~g} / \mathrm{L} \mathrm{KCl}, 0.192 \mathrm{~g} / \mathrm{L} \mathrm{KBr}, 0.052 \mathrm{~g} / \mathrm{L} \mathrm{H} \mathrm{H}_{3} \mathrm{BO}_{3}$, $0.08 \mathrm{~g} / \mathrm{L} \mathrm{SrCl}_{2} \times 6 \mathrm{H}_{2} \mathrm{O}$ and $0.006 \mathrm{~g} / \mathrm{L} \mathrm{NaF}$ and was freshly prepared before addition to the base solution. Hutner's basal salt solution was prepared by first dissolving $10 \mathrm{~g}$ nitrilotriacetic acid (NTA) in $700 \mathrm{~mL}$ double distilled water and adjusting the $\mathrm{pH}$ to 7.2 using $5 \mathrm{M} \mathrm{KOH}$. After that, the following compounds were added: $29.7 \mathrm{~g} \mathrm{MgSO}_{4} \times 7 \mathrm{H}_{2} \mathrm{O}, 3.34 \mathrm{~g} \mathrm{CaCl}_{2}$ $\times 2 \mathrm{H}_{2} \mathrm{O}, 0.01267 \mathrm{~g} \mathrm{Na}_{2} \mathrm{MoO}_{4} \times 2 \mathrm{H}_{2} \mathrm{O}, 0.099 \mathrm{~g}$ $\mathrm{FeSO}_{4} \times 7 \mathrm{H}_{2} \mathrm{O}$ and $50 \mathrm{~mL}$ metal salt solution 44 . The solution was filled up to $1 \mathrm{~L}$, sterilised by filtering and stored at $4{ }^{\circ} \mathrm{C}$. Metal salt solution 44 consisted of $250 \mathrm{mg} / \mathrm{L} \mathrm{Na} \mathrm{NaDTA}_{2} 1095 \mathrm{mg} / \mathrm{L} \mathrm{ZnSO}_{4} \times 7 \mathrm{H}_{2} \mathrm{O}$, $500 \mathrm{mg} / \mathrm{L} \mathrm{FeSO}_{4} \times 7 \mathrm{H}_{2} \mathrm{O}, 154 \mathrm{mg} / \mathrm{L} \mathrm{MnSO}_{4} \times \mathrm{H}_{2} \mathrm{O}$, $39.5 \mathrm{mg} / \mathrm{L} \mathrm{CuSO}_{4} \times 5 \mathrm{H}_{2} \mathrm{O}, 20.3 \mathrm{mg} / \mathrm{L} \mathrm{CoCl} \mathrm{Cl}_{2} \times 6$ $\mathrm{H}_{2} \mathrm{O}$ and $17.7 \mathrm{mg} / \mathrm{L} \mathrm{Na}_{2} \mathrm{~B}_{4} \mathrm{O}_{7} \times 10 \mathrm{H}_{2} \mathrm{O}$. In the first step, EDTA was dissolved and, if required, a few drops of concentrated $\mathrm{H}_{2} \mathrm{SO}_{4}$ were added to retard precipitation of heavy metal ions. Metal salt solution 44 was sterilised by filtration and stored at $4{ }^{\circ} \mathrm{C}$. Vitamin 
solution contained per liter: $10 \mathrm{mg} p$-aminobenzoic acid, $4 \mathrm{mg}$ biotin, $20 \mathrm{mg}$ pyridoxine hydrochloride, $10 \mathrm{mg}$ thiamine hydrochloride, $10 \mathrm{mg}$ Ca-pantothenate, $4 \mathrm{mg}$ folic acid, $10 \mathrm{mg}$ riboflavin, $10 \mathrm{mg}$ nicotinamide and $0.2 \mathrm{mg}$ vitamin B12. p-Aminobenzoic acid was dissolved first and the solution was sterilised by filtration and stored in the dark at $4{ }^{\circ} \mathrm{C}$. The trace element solution containing $1.5 \mathrm{~g} / \mathrm{L}$ Na-nitrilotriacetate, $500 \mathrm{mg} / \mathrm{L} \mathrm{MnSO}_{4} \times \mathrm{H}_{2} \mathrm{O}, 100 \mathrm{mg} / \mathrm{L} \mathrm{FeSO}_{4} \times 7$ $\mathrm{H}_{2} \mathrm{O}, \quad 100 \mathrm{mg} / \mathrm{L} \quad \mathrm{Co}\left(\mathrm{NO}_{3}\right)_{2} \times 6 \quad \mathrm{H}_{2} \mathrm{O}, \quad 100 \mathrm{mg} / \mathrm{L}$ $\mathrm{ZnCl}_{2}, 50 \mathrm{mg} / \mathrm{L} \mathrm{NiCl} \mathrm{N}_{2} \times 6 \mathrm{H}_{2} \mathrm{O}, 50 \mathrm{mg} / \mathrm{L} \mathrm{H}_{2} \mathrm{SeO}_{3}$, $10 \mathrm{mg} / \mathrm{L} \mathrm{CuSO}_{4} \times 5 \mathrm{H}_{2} \mathrm{O}, 10 \mathrm{mg} / \mathrm{L} \mathrm{AlK}\left(\mathrm{SO}_{4}\right)_{2} \times 12$ $\mathrm{H}_{2} \mathrm{O}, 10 \mathrm{mg} / \mathrm{L} \mathrm{H}_{3} \mathrm{BO}_{3}, 10 \mathrm{mg} / \mathrm{L} \mathrm{NaMoO} \mathrm{N}_{4} \times 2 \mathrm{H}_{2} \mathrm{O}$ and $10 \mathrm{mg} / \mathrm{L} \mathrm{Na} \mathrm{NO}_{4} \times 2 \mathrm{H}_{2} \mathrm{O}$ was sterilised by filtration and stored in the dark at $4{ }^{\circ} \mathrm{C}$.

Strain Pan $54^{\mathrm{T}}$ was isolated on the 10th of September 2013 from an algal surface in hydrothermal area 26 (sampling site $38.6392 \mathrm{~N}, 15.1051 \mathrm{E}$ ) close to the island Panarea in the north of Sicily, Italy. Algae leaves were initially washed with $0.5 \times$ artificial sea water (ASW) and placed on M1H ASW solid medium (lacking NAG) containing $8 \mathrm{~g} / \mathrm{L}$ gelrite additionally supplemented with $20 \mathrm{mg} / \mathrm{L}$ cycloheximide, $1000 \mathrm{mg} /$ $\mathrm{L}$ streptomycin and $200 \mathrm{mg} / \mathrm{L}$ ampicillin. Two different $\mathrm{pH}$ values (6.5 and 8.0) were tested and plates were cultivated at $20{ }^{\circ} \mathrm{C}$ for $2-3$ weeks. Isolated colonies were then streaked on a new plate and maintained in liquid M1H NAG ASW medium. Initial amplification and sequencing of the 16S rRNA gene was performed as previously described (Rast et al. 2017).

Deposition of genomic data

Genome data (acc. no. SJPG00000000) and the 16S rRNA gene sequence (acc. no. MK554545) were deposited in the GenBank database.

Light microscopy

Phase contrast (Phaco) analyses were performed employing a Nikon Eclipse Ti inverted microscope with a Nikon DS-Ri2 camera (blue LED). Specimens were immobilised in MatTek glass bottom dishes ( $35 \mathrm{~mm}$, No. 1.5) employing a $1 \%$ agarose cushion (Will et al. 2018). Images were analysed using the Nikon NIS-Elements software (version 4.3). To determine the cell size, at least 100 representative cells were counted manually (Annotations and Measurements, NIS-Elements) or by using the NIS-
Elements semi-automated object count tool (smooth: $4 \times$, clean: $4 \times$, fill holes: on, separate: $4 \times$ ).

\section{Electron microscopy}

For field emission scanning electron microscopy (FESEM) bacteria were fixed in $1 \%(\mathrm{v} / \mathrm{v})$ formaldehyde in HEPES buffer ( $3 \mathrm{mM}$ HEPES, $0.3 \mathrm{mM} \mathrm{CaCl}_{2}$, $0.3 \mathrm{mM} \mathrm{MgCl}_{2}, 2.7 \mathrm{mM}$ sucrose, $\mathrm{pH}$ 6.9) for $1 \mathrm{~h}$ on ice and washed once employing the same buffer (Rast et al. 2017). Cover slips with a diameter of $12 \mathrm{~mm}$ were coated with a poly-L-lysine solution (SigmaAldrich) for $10 \mathrm{~min}$, washed in distilled water and airdried. $50 \mu \mathrm{L}$ of the fixed bacteria solution was placed on a cover slip and allowed to settle for $10 \mathrm{~min}$. Cover slips were then fixed in $1 \%$ glutaraldehyde in TE buffer (20 mM TRIS, $1 \mathrm{mM}$ EDTA, pH 6.9) for $5 \mathrm{~min}$ at room temperature and subsequently washed twice with TE buffer before dehydrating in a graded series of acetone $(10,30,50,70,90,100 \%)$ on ice for $10 \mathrm{~min}$ at each concentration. Samples from the $100 \%$ acetone step were brought to room temperature before placing them in fresh $100 \%$ acetone. Samples were then subjected to critical-point drying with liquid $\mathrm{CO}_{2}$ (CPD 300, Leica). Dried samples were covered with a gold/palladium (80/20) film by sputter coating (SCD 500 , Bal-Tec) before examination in a field emission scanning electron microscope (Zeiss Merlin) using the Everhart Thornley HESE2 detector and the inlens SE detector in a 25:75 ratio at an acceleration voltage of $5 \mathrm{kV}$. Transmission electron microscopy (TEM) was performed as described before (Kohn et al. 2016).

Physiological analyses

For determination of the $\mathrm{pH}$ optimum $100 \mathrm{mM}$ HEPES was used for cultivations at $\mathrm{pH}$ 7.0, 7.5 and 8.0. For cultivation at $\mathrm{pH} 5.0$ and 6.0 HEPES was replaced by $100 \mathrm{mM}$ 2-( $N$-morpholino)ethanesulfonic acid (MES), whereas $100 \mathrm{mM} \mathrm{N}$-cyclohexyl-2aminoethanesulfonic acid (CHES) served as a buffering agent at $\mathrm{pH} 9.0$ and 10.0. Cultivations for determination of the $\mathrm{pH}$ optimum were performed at $28{ }^{\circ} \mathrm{C}$. For determination of the temperature optimum Pan5 $4^{\mathrm{T}}$ was cultivated in M1H NAG ASW medium at $\mathrm{pH} 7.5$ at different temperatures ranging from 10 to $40{ }^{\circ} \mathrm{C}$. Fatty acid composition of Pan $54^{\mathrm{T}}$ was analysed based on a protocol described previously (Kohn et al. 2016). 
Phylogenetic analyses

The genome of strain Pan54 ${ }^{\mathrm{T}}$ was published previously (Wiegand et al. 2019) and is available from GenBank under acc. no. SJPG00000000. The GenBank acc. no. of the 16S rRNA gene is MK554545. 16S rRNA gene phylogeny was computed for strain Pan54 ${ }^{\mathrm{T}}$, the type strains of all described planctomycetal species (May 2019) and all isolates recently published (Wiegand et al. 2019). The 16S rRNA gene sequences were aligned with SINA (Pruesse et al. 2012). The phylogenetic analysis was done employing a maximum likelihood (ML) approach with 1,000 bootstraps, the nucleotide substitution model GTR, gamma distribution and estimation of proportion of invariable sites (GTRGAMMAI option) (Stamatakis 2014). Three 16S rRNA genes of bacterial strains from the PVC superphylum served as outgroup. The $r p o B$ nucleotide sequences (encoding the RNA polymerase $\beta$-subunit) were taken from publicly available genome annotations and the sequence identities were determined as described previously (Bondoso et al. 2013) with Clustal Omega (Sievers et al. 2011) alignment and matrix calculation upon extracting only those parts of the sequence that would have been sequenced with the described primer set. The average nucleotide identity (ANI) was calculated using OrthoANI (Lee et al. 2016). The average amino acid identity (AAI) was gained with the aai.rb script of the enveomics collection (Rodriguez-R and Konstantinidis 2016). The percentage of conserved proteins (POCP) was calculated as described before (Qin et al. 2014).

\section{Results and discussion}

\section{Phylogenetic analysis}

In our phylogenetic analysis Pan54 $4^{\mathrm{T}}$ appears in a monophyletic clade with its closest relative Rubinisphaera brasiliensis DSM $5305^{\mathrm{T}}$ (Fig. 1). R. brasiliensis DSM $5305^{\mathrm{T}}$ was originally isolated from a water sample of Lagoa Vermelha, a salt pit near Rio de Janeiro, Brasil, initially described as "Planctomyces brasiliensis" in 1989 and was later reclassified (Scheuner et al. 2014; Schlesner 1989). R. brasiliensis is currently the only validly described species within the genus Rubinisphaera. Pan54 ${ }^{\mathrm{T}}$ and $R$. brasiliensis DSM $5305^{\mathrm{T}}$ share a $16 \mathrm{~S}$ rRNA gene sequence identity of $96.2 \%$. This value is below the threshold of $98.7 \%$ for a novel species (Stackebrandt and Ebers 2006), but above the threshold for a novel planctomycetal genus of $94.5 \%$ (Yarza et al. 2014). Both strains share 76.5\% $r p o B$ gene identity, which is below the $96.3 \%$ cutoff proposed to distinguish between different planctomycetal species and above the threshold for novel genera of $72 \%$ sequence identity (Bondoso et al. 2013). Average nucleotide identity (ANI) between both strains is $69.7 \%$ and distinctly below the species threshold of $95-96 \%$ for ANIb (ANI calculated with the BLAST algorithm) (Kim et al. 2014). The average amino acid identity (AAI) between Pan54 ${ }^{\mathrm{T}}$ and its relative $R$. brasiliensis DSM $5305^{\mathrm{T}}$ is $58.1 \%$ and thus fits in the range for species belonging to the same bacterial genus (Rodriguez et al. 2018). Finally, the percentage of conserved proteins (POCP) of $62.3 \%$ between both strains also indicates that they belong to the same genus, as a prokaryotic genus is proposed to be formed by a group of species with pairwise POCP values higher than 50\% (Qin et al. 2014). Close relatives apart from $R$. brasiliensis DSM $5305^{\mathrm{T}}$ include Planctomicrobium piriforme $\mathrm{P}^{\mathrm{T}}$ (Kulichevskaya et al. 2015), Gimesia maris DSM $8797^{\mathrm{T}}$ (Scheuner et al. 2014), Fuerstiella marisgermanici $\mathrm{NH} 11^{\mathrm{T}}$ (formerly designated "Fuerstia marisgermanicae") (Kohn et al. 2019a, 2016) and species of the Planctopirus genus (Fig. 1).

Morphological, physiological and biochemical analyses

For a morphological characterization, Pan54 ${ }^{\mathrm{T}}$ cells were harvested during the exponential growth phase. Pan $54^{\mathrm{T}}$ cells were found to be pear-shaped $(1.6 \pm 0.2 \mu \mathrm{m} \times 0.8 \pm 0.1 \mu \mathrm{m}) \quad$ (Fig. $2 \mathrm{a}-\mathrm{c}) \quad$ and form strong aggregates and biofilms. Cells have a textured surface and contain evenly distributed crateriform structures (Fig. 2d, e). Pan54 ${ }^{\mathrm{T}}$ divides by polar budding (Fig. 2a). Daughter cells have the same shape as mother cells. Thin sections of Pan $54^{\mathrm{T}}$ cells show a condensed nucleoid and cytoplasmic invaginations (Fig. 2f, g). Colonies are white indicating a lack of carotenoids as pigmenting compounds. Detailed information on morphology, locomotion and cell division is summarised in Table $1 . \operatorname{Pan} 54^{\mathrm{T}}$ has a very similar morphology as $R$. brasiliensis. In the direct comparison Pan54 ${ }^{\mathrm{T}}$ has a slightly elongated shape and crateriform structures appear to be more 


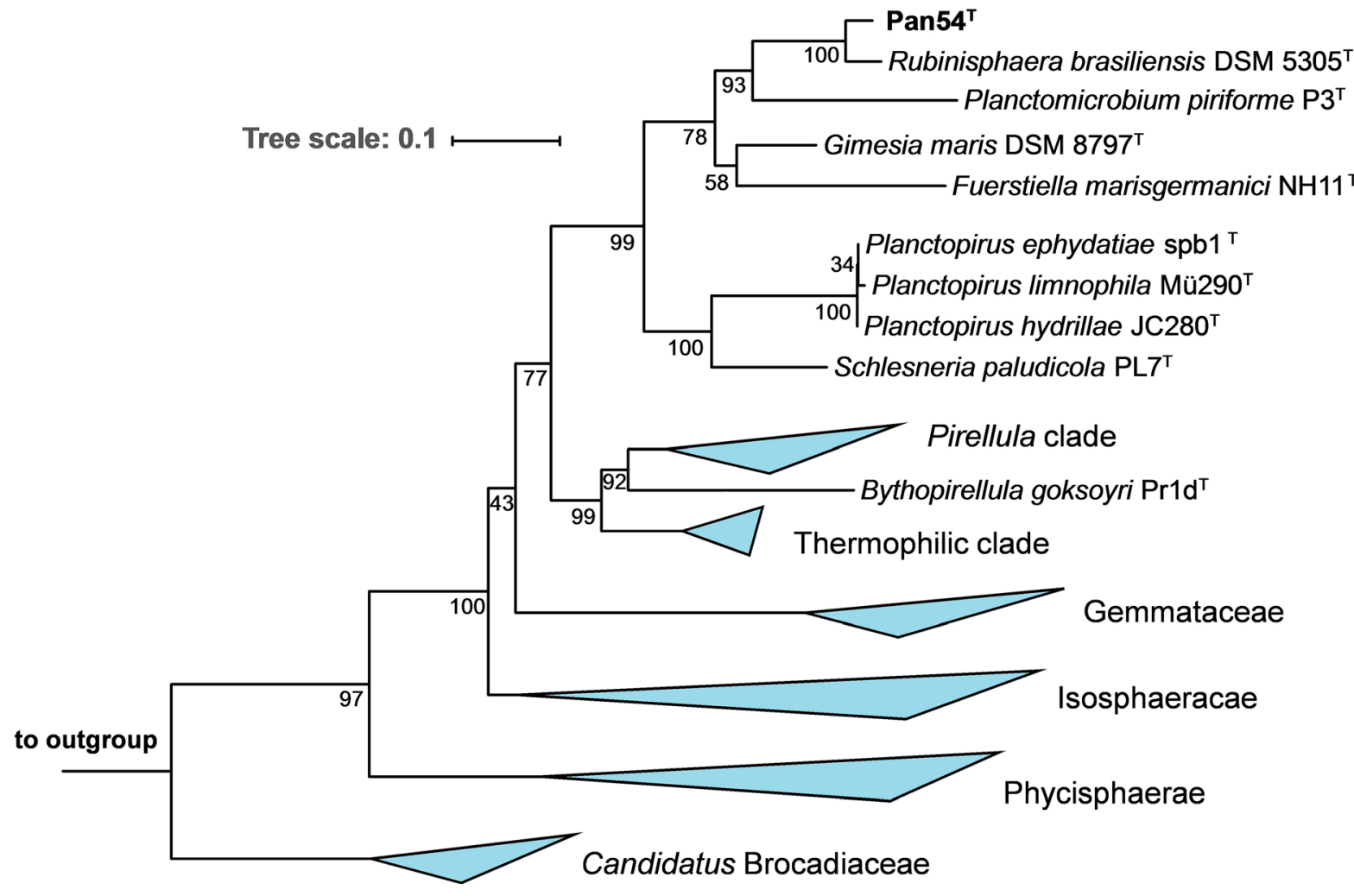

Fig. 1 Phylogenetic analysis. The phylogenetic tree highlighting the position of Pan54 ${ }^{\mathrm{T}}$ is depicted. 16S rRNA gene phylogeny was computed using the maximum likelihood method. Bootstrap values after 1000 resamplings (in \%) are given at the nodes. The outgroup consists of three 16S rRNA

pronounced. Similar to $R$. brasiliensis rosette formation was observed rather than formation of larger aggregates (Scheuner et al. 2014). The colony colour of non-pigmented Pan54 ${ }^{\mathrm{T}}$ differs from the yellow to orange pigmentation of $R$. brasiliensis.

In physiological experiments, Pan54 ${ }^{\mathrm{T}}$ grew at a temperature range of $14-27{ }^{\circ} \mathrm{C}$ (Fig. 3a) and a $\mathrm{pH}$ range of $6.0-10.0$ (Fig. 3b), but failed to grow at $30{ }^{\circ} \mathrm{C}$ or above (Fig. 3a). The optimal conditions turned out to be $\mathrm{pH} 9.0$ and $26^{\circ} \mathrm{C}$. The observed temperature optimum of Pan $54^{\mathrm{T}}$ is lower compared to R. brasiliensis $\left(30-33^{\circ} \mathrm{C}\right)($ Schlesner 1989). R. brasiliensis even grows at temperatures of $37{ }^{\circ} \mathrm{C}$ (Schlesner 1989), while Pan $54^{\mathrm{T}}$ failed to grow at $30^{\circ} \mathrm{C}$ or higher. Taken together, growth of Pan54 ${ }^{\mathrm{T}}$ is mesophilic and slightly alkaliphilic. A maximal growth rate of $0.039 \mathrm{~h}^{-1}$ was observed under the given conditions corresponding to a generation time of $18 \mathrm{~h}$ (Fig. 3). This value is in the range of $0.01-0.09 \mathrm{~h}^{-1}$ (generation times of 8-70 h), genes from the PVC superphylum. The "Pirellula clade" includes species of the genera Rhodopirellula, Rubripirellula, Roseimaritima, Mariniblastus, Pirellula and Blastopirellula. The "Thermophilic clade" comprises the genera Thermostilla, Thermogutta and Thermopirellula

which we typically observed for planctomycetal strains isolated and characterised in our lab so far.

Major fatty acids of Pan54 ${ }^{\mathrm{T}}$ include summed feature 3 (palmitoleic acid $(16: 1 \omega 7 \mathrm{c}), 15: 0$ iso 2-OH) (57\%), palmitic acid (16:0) (36\%) and cisvaccenic acid $(18: 1 \omega 7 \mathrm{c})(5 \%)$ (Table 2$)$. The composition is similar to $R$. brasiliensis in which 16:0, 16:1 and 18:1 were also found as the major fatty acids (Scheuner et al. 2014). However, the composition appears to be more restricted to these three in Pan54 ${ }^{\mathrm{T}}$ as other fatty acid were only detected in traces $(<$ $0.5 \%$ ) in this strain.

Genomic characteristics

The genome of Pan54 $4^{\mathrm{T}}$ has a size of $6.7 \mathrm{Mb}$ and is slightly larger compared to $R$. brasiliensis $(6.0 \mathrm{Mb})$, whereas the GC content is lower $\left(48.8 \%\right.$ for Pan $54^{\mathrm{T}}$, $56.4 \%$ for $R$. brasiliensis). Relevant genome characteristics are summarised in Table 1. Automated gene 
Fig. 2 Microscopy images and cell size plot of Pan54 ${ }^{\mathrm{T}}$. Pictures from light microscopy (LM) (a, b), scanning electron microscopy (SEM) (d, e) and transmission electron microscopy (TEM) (f, g) are shown. The scale bars are $1 \mu \mathrm{m}$. For determination of the cell size (c) at least 100 representative cells were counted manually or by using a semi-automated object count tool during scanning electron microscopy
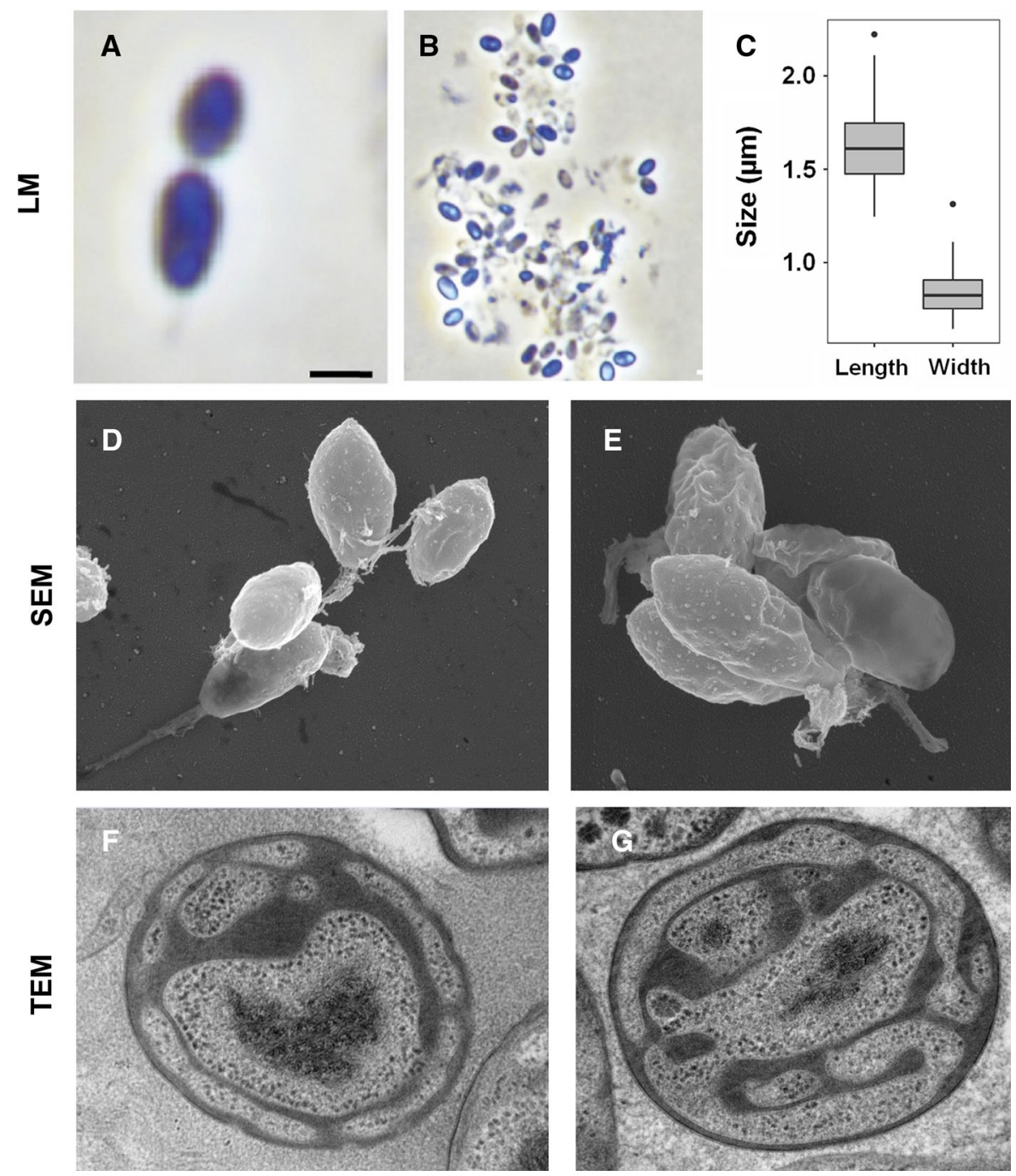

prediction and annotation identified 5275 putative protein-encoding genes, of which $42 \%$ (2229 genes) are annotated as hypothetical proteins. The calculated values correspond to 787 protein-coding genes per $\mathrm{Mb}$ and a coding density of $85 \%$. Except for differences in GC content no striking differences between genome features of Pan54 $4^{\mathrm{T}}$ and $R$. brasiliensis DSM $5305^{\mathrm{T}}$ were observed (Table 1). The number of 16S rRNA in both strains is identical and number of tRNAs is very similar.

\section{Conclusion}

Based on the data collected during strain characterisation, Pan $54^{\mathrm{T}}$ represents a novel species within the genus Rubinisphaera. We propose the name Rubinisphaera italica sp. nov. and present $\operatorname{Pan} 54^{\mathrm{T}}$ as the type strain of the species.

Emended description of the genus Rubinisphaera Scheuner et al. (2014)

The description of the genus Rubinisphaera given previously (Scheuner et al. 2014), with the following modification: The GC content is between 48 and $57 \%$.

\section{Description of Rubinisphaera italica sp. nov.}

Rubinisphaera italica (i.ta'li.ca. L. fem. adj. italica of Italy; corresponding to the isolation of the strain from Italy). Cells are pear-shaped (length: $1.6 \pm 0.2 \mu \mathrm{m}$, 
Table 1 Phenotypic and genotypic features of Pan5 $4^{\mathrm{T}}$ in comparison to $R$. brasiliensis DSM 5305 ${ }^{\mathrm{T}}$

(Scheuner et al. 2014; Schlesner 1989)

n.o. not observed, $n / a$ not available

Fig. 3 Temperature and $\mathrm{pH}$ optimum of strain Pan54 ${ }^{\mathrm{T}}$. Data points show average growth rates obtained after cultivation in M1H NAG ASW medium in biological triplicates. Cultivations at different temperatures

(a) were performed at $\mathrm{pH}$ 7.5. Cultivations at different $\mathrm{pH}$ values (b) were conducted at $28^{\circ} \mathrm{C}$

\begin{tabular}{|c|c|c|}
\hline Characteristics & $\operatorname{Pan} 54^{\mathrm{T}}$ & 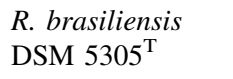 \\
\hline \multicolumn{3}{|l|}{ Phenotypic features } \\
\hline Color & White & Yellow to orange \\
\hline Size & $1.6 \times 0.8 \mu \mathrm{m}$ & $0.7-1.8 \mu \mathrm{m}$ \\
\hline Shape & Pear-shaped & Spherical to ovoid \\
\hline Aggregates & Yes & Yes \\
\hline Division & Budding & Budding \\
\hline Dimorphic life cycle & n.o. & Yes \\
\hline Flagella & n.o. & Yes \\
\hline Crateriform structures & Yes, overall & Yes \\
\hline Fimbriae & Yes, polar matrix or fiber & Yes \\
\hline Capsule & n.o. & n.o. \\
\hline Bud shape & Like mother cell & Like mother cell \\
\hline Budding pole & Polar & Polar \\
\hline Stalk & Yes & Yes \\
\hline Holdfast structure & n.o. & Yes \\
\hline \multicolumn{3}{|l|}{ Genotypic features } \\
\hline Genome size $[\mathrm{bp}]$ & $6,704,479$ & $6,006,602$ \\
\hline Plasmids [bp] & n.o. & n.o. \\
\hline $\mathrm{GC}[\%]$ & $48.8 \pm 0.5$ & 56.4 \\
\hline Completeness [\%] & 96.55 & 94.83 \\
\hline Contamination [\%] & 1.88 & 3.45 \\
\hline Protein-coding genes & 5275 & 4824 \\
\hline Hypothetical proteins & 2229 & 2581 \\
\hline Protein-coding genes/Mb & 787 & 803 \\
\hline Coding density [\%] & 85.4 & 86.1 \\
\hline 16S rRNA genes & 2 & 2 \\
\hline tRNA genes & 58 & 50 \\
\hline
\end{tabular}

A

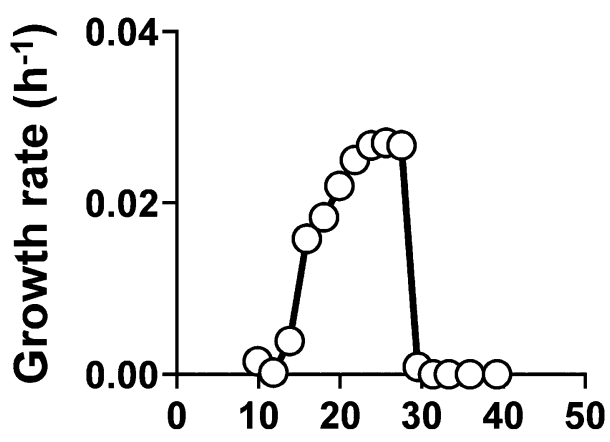

Temperature $\left({ }^{\circ} \mathrm{C}\right)$
B

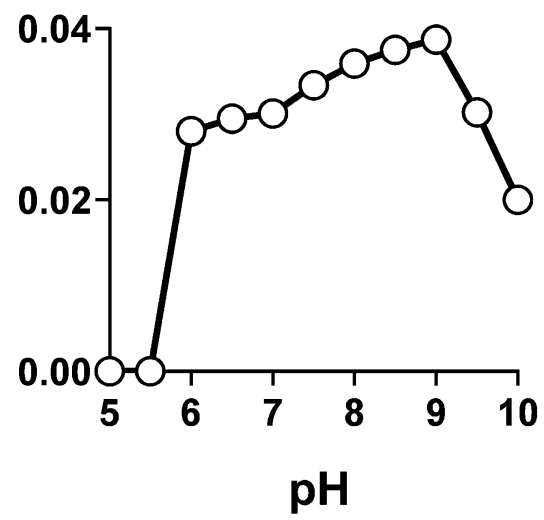

width: $0.8 \pm 0.1 \mu \mathrm{m}$ ), form aggregates and divide by polar budding. Cells grow at ranges of $14-27{ }^{\circ} \mathrm{C}$ (optimum $26^{\circ} \mathrm{C}$ ) and $\mathrm{pH}$ 6.0-10.0 (optimum 9.0).
Colonies are white. The genome (acc. no. SJPG00000000) and 16S rDNA sequence (acc. no. MK554545) are available from the GenBank database. 
Table 2 Fatty acid composition of Pan $54^{\mathrm{T}}$

\begin{tabular}{lc}
\hline Fatty acid & Share in $\%$ \\
\hline $12: 03-\mathrm{OH}$ & 0.06 \\
$14: 1 \omega 5 \mathrm{c}$ & 0.10 \\
$14: 0$ & 0.21 \\
$15: 1 \omega 6 \mathrm{c}$ & 0.13 \\
$15: 0$ & 0.26 \\
Summed feature 3 & 56.53 \\
$(16: 1 \omega 7 \mathrm{c}, 15: 0$ iso 2-OH) & \\
$16: 1 \omega 5 \mathrm{c}$ & 0.21 \\
$16: 0$ & 35.82 \\
$17: 1 \omega 8 \mathrm{c}$ & 0.15 \\
$17: 0$ & 0.10 \\
$18: 1 \omega 9 \mathrm{c}$ & 1.22 \\
$18: 1 \omega 7 \mathrm{c}$ & 4.73 \\
$18: 0$ & 0.37 \\
$20: 1 \omega 7 \mathrm{c}$ & 0.11 \\
\hline
\end{tabular}

The genome has a GC content of $48.8 \%$ and is $6.70 \mathrm{Mb}$ in length. The proposed type strain is Pan $54^{\mathrm{T}}$ (DSM 29369 = LMG 29789) isolated from an algal surface at a hydrothermal area close to Panarea, Italy.

Acknowledgements Part of this work was funded by the Deutsche Forschungsgemeinschaft (DFG) Grant No. KA 4967/1-1 and JO 893/4-1, Grant ALWOP.308 of the Nederlandse Organisatie voor Wetenschappelijk Onderzoek (NWO) grant and SIAM (Soehngen Institute for Anaerobic Microbiology) Grant No. 024002002. We thank the Scientific Diving Center of Bergakademie Freiberg (Germany) as well as Thomas Pohl, Peter Hornburger and all participants of the 2013 Panarea Expedition for support during sampling. We thank Ina Schleicher for skillful technical assistance. Lastly, we would like to thank Brian Tindall and Regine Fähnrich as well as the BCCM/LMG Bacteria collection for on-going support during strain deposition.

Author contributions NK wrote the manuscript, analyzed the data and prepared the figures, SW and MJ performed the genomic and phylogenetic analysis, $\mathrm{AH}$ isolated the strain and performed the initial strain cultivation and deposition, SHP and $\mathrm{CB}$ performed the light microscopic analysis, MSMJ contributed to text preparation and revised the manuscript, MR performed the electron microscopic analysis, CJ and MJ took the samples in Panarea, Italy. CJ supervised the study. All authors read and approved the final version of the manuscript.

\section{Compliance with ethical standards}

Conflict of interest The authors declare that they have no conflict of interest.

Ethical statement This article does not contain any studies with animals performed by any of the authors.

Open Access This article is distributed under the terms of the Creative Commons Attribution 4.0 International License (http:// creativecommons.org/licenses/by/4.0/), which permits unrestricted use, distribution, and reproduction in any medium, provided you give appropriate credit to the original author(s) and the source, provide a link to the Creative Commons license, and indicate if changes were made.

\section{References}

Bengtsson MM, Øvreås L (2010) Planctomycetes dominate biofilms on surfaces of the kelp Laminaria hyperborea. BMC Microbiol 10:261

Bengtsson MM, Sjøtun K, Lanzén A, Øvreås L (2012) Bacterial diversity in relation to secondary production and succession on surfaces of the kelp Laminaria hyperborea. ISME J 6:2188-2198

Boedeker C, Schuler M, Reintjes G, Jeske O, van Teeseling MC, Jogler M, Rast P, Borchert D, Devos DP, Kucklick M, Schaffer M, Kolter R, van Niftrik L, Engelmann S, Amann R, Rohde M, Engelhardt H, Jogler C (2017) Determining the bacterial cell biology of Planctomycetes. Nat Commun $8: 14853$

Bondoso J, Albuquerque L, Nobre MF, Lobo-da-Cunha A, da Costa MS, Lage OM (2015) Roseimaritima ulvae gen. nov., sp. nov. and Rubripirellula obstinata gen. nov., sp. nov. two novel planctomycetes isolated from the epiphytic community of macroalgae. Syst Appl Microbiol 38:8-15

Bondoso J, Balague V, Gasol JM, Lage OM (2014) Community composition of the Planctomycetes associated with different macroalgae. FEMS Microbiol Ecol 88:445-456

Bondoso J, Godoy-Vitorino F, Balague V, Gasol JM, Harder J, Lage OM (2017) Epiphytic Planctomycetes communities associated with three main groups of macroalgae. FEMS Microbiol Ecol 93(3):fiw255

Bondoso J, Harder J, Lage OM (2013) rpoB gene as a novel molecular marker to infer phylogeny in Planctomycetales. Antonie Van Leeuwenhoek 104:477-488

Devos DP (2014a) PVC bacteria: variation of, but not exception to, the Gram-negative cell plan. Trends Microbiol 22:14-20

Devos DP (2014b) Re-interpretation of the evidence for the PVC cell plan supports a Gram-negative origin. Antonie Van Leeuwenhoek 105:271-274

Devos DP, Jogler C, Fuerst JA (2013) The 1st EMBO workshop on PVC bacteria-Planctomycetes-Verrucomicrobia-Chlamydiae superphylum: exceptions to the bacterial definition? Antonie Van Leeuwenhoek 104:443-449

Devos DP, Reynaud EG (2010) Evolution. Intermediate steps. Science 330:1187-1188 
Devos DP, Ward NL (2014) Mind the PVCs. Environ Microbiol 16:1217-1221

Frank O, Michael V, Pauker O, Boedeker C, Jogler C, Rohde M, Petersen J (2014) Plasmid curing and the loss of grip-the 65-kb replicon of Phaeobacter inhibens DSM 17395 is required for biofilm formation, motility and the colonization of marine algae. Syst Appl Microbiol 38:120-127

Fuerst JA, Sagulenko E (2011) Beyond the bacterium: planctomycetes challenge our concepts of microbial structure and function. Nat Rev Microbiol 9:403-413

Fuerst JA, Webb RI (1991) Membrane-bounded nucleoid in the eubacterium Gemmata obscuriglobus. Proc Natl Acad Sci USA 88:8184-8188

Gabbianelli G, Gillot P, Lanzafame G, Romagnoli C, Rossi P (1990) Tectonic and volcanic evolution of Panarea (Aeolian islands, Italy). Mar Geol 92:313-326

Graca AP, Calisto R, Lage OM (2016) Planctomycetes as novel source of bioactive molecules. Front Microbiol 7:1241

Gugliandolo C, Lentini V, Bunk B, Overmann J, Italiano F, Maugeri TL (2015) Changes in prokaryotic community composition accompanying a pronounced temperature shift of a shallow marine thermal brine pool (Panarea Island, Italy). Extremophiles 19:547-559

Jeske O, Jogler M, Petersen J, Sikorski J, Jogler C (2013) From genome mining to phenotypic microarrays: Planctomycetes as source for novel bioactive molecules. Antonie Van Leeuwenhoek 104:551-567

Jeske O, Schüler M, Schumann P, Schneider A, Boedeker C, Jogler M, Bollschweiler D, Rohde M, Mayer C, Engelhardt H, Spring S, Jogler C (2015) Planctomycetes do possess a peptidoglycan cell wall. Nat Commun 6:7116

Jogler C, Glöckner FO, Kolter R (2011) Characterization of Planctomyces limnophilus and development of genetic tools for its manipulation establish it as a model species for the phylum Planctomycetes. Appl Environ Microbiol 77:5826-5829

Jogler C, Waldmann J, Huang X, Jogler M, Glöckner FO, Mascher T, Kolter R (2012) Identification of proteins likely to be involved in morphogenesis, cell division, and signal transduction in Planctomycetes by comparative genomics. J Bacteriol 194:6419-6430

Jogler M, Jogler C (2013) Towards the development of genetic tools for Planctomycetes. In: Fuerst JA (ed) Planctomycetes: cell structure, origins and biology. Springer, Berlin, pp 141-164

Kim M, Oh H-S, Park S-C, Chun J (2014) Towards a taxonomic coherence between average nucleotide identity and $16 \mathrm{~S}$ rRNA gene sequence similarity for species demarcation of prokaryotes. Int J Syst Evol Microbiol 64:346-351

Kohn T, Heuer A, Jogler M, Vollmers J, Boedeker C, Bunk B, Rast P, Borchert D, Glöckner I, Freese HM (2019a) Corrigendum: Fuerstia marisgermanicae gen. nov., sp. nov., an unusual member of the phylum Planctomycetes from the German Wadden Sea. Front Microbiol 10:1029

Kohn T, Wiegand S, Boedeker C, Rast P, Heuer A, Jetten MSM, Schüler M, Becker S, Rohde C, Müller R-W, Brümmer F, Rohde M, Engelhardt H, Jogler M, Jogler C (2019b) Planctopirus ephydatiae, a novel Planctomycete isolated from a freshwater sponge. Syst Appl Microbiol. https://doi. org/10.1016/j.syapm.2019.126022
Kohn T, Heuer A, Jogler M, Vollmers J, Boedeker C, Bunk B, Rast P, Borchert D, Glöckner I, Freese HM, Klenk HP, Overmann J, Kaster AK, Wiegand S, Rohde M, Jogler C (2016) Fuerstia marisgermanicae gen. nov., sp. nov., an unusual member of the phylum Planctomycetes from the German Wadden Sea. Front Microbiol 7:2079

König E, Schlesner H, Hirsch P (1984) Cell wall studies on budding bacteria of the Planctomyces/Pasteuria group and on a Prosthecomicrobium sp. Arch Microbiol 138:200-205

Kulichevskaya IS, Ivanova AA, Detkova EN, Rijpstra WIC, Damste JSS, Dedysh SN (2015) Planctomicrobium piriforme gen. nov., sp. nov., a stalked planctomycete from a littoral wetland of a boreal lake. Int J Syst Evol Microbiol 65:1659-1665

Lachnit T, Fischer M, Kunzel S, Baines JF, Harder T (2013) Compounds associated with algal surfaces mediate epiphytic colonization of the marine macroalga Fucus vesiculosus. FEMS Microbiol Ecol 84:411-420

Lage OM, Bondoso J (2014) Planctomycetes and macroalgae, a striking association. Front Microbiol 5:267

Lee I, Ouk Kim Y, Park SC, Chun J (2016) OrthoANI: An improved algorithm and software for calculating average nucleotide identity. Int $\mathrm{J}$ Syst Evol Microbiol 66:1100-1103

Lindsay MR, Webb RI, Fuerst JA (1997) Pirellulosomes: a new type of membrane-bounded cell compartment in planctomycete bacteria of the genus Pirellula. Microbiol 143:739-748

Lonhienne TG, Sagulenko E, Webb RI, Lee KC, Franke J, Devos DP, Nouwens A, Carroll BJ, Fuerst JA (2010) Endocytosis-like protein uptake in the bacterium Gemmata obscuriglobus. Proc Natl Acad Sci USA 107:12883-12888

Pilhofer M, Rappl K, Eckl C, Bauer AP, Ludwig W, Schleifer KH, Petroni G (2008) Characterization and evolution of cell division and cell wall synthesis genes in the bacterial phyla Verrucomicrobia, Lentisphaerae, Chlamydiae, and Planctomycetes and phylogenetic comparison with rRNA genes. J Bacteriol 190:3192-3202

Pruesse E, Peplies J, Glöckner FO (2012) SINA: accurate highthroughput multiple sequence alignment of ribosomal RNA genes. Bioinformatics 28:1823-1829

Qin Q-L, Xie B-B, Zhang X-Y, Chen X-L, Zhou B-C, Zhou J, Oren A, Zhang Y-Z (2014) A proposed genus boundary for the prokaryotes based on genomic insights. J Bacteriol 196:2210-2215

Rast P, Glöckner I, Boedeker C, Jeske O, Wiegand S, Reinhardt R, Schumann P, Rohde M, Spring S, Glöckner FO (2017) Three novel species with peptidoglycan cell walls form the new genus Lacunisphaera gen. nov. in the family Opitutaceae of the verrucomicrobial subdivision 4. Front Microbiol 8:202

Rivas-Marin E, Canosa I, Santero E, Devos DP (2016) Development of genetic tools for the manipulation of the Planctomycetes. Front Microbiol 7:914

Rodriguez-R LM, Konstantinidis KT (2016) The enveomics collection: a toolbox for specialized analyses of microbial genomes and metagenomes. PeerJ Preprints 4:e1900v1

Rodriguez RL, Gunturu S, Harvey WT, Rossello-Mora R, Tiedje JM, Cole JR, Konstantinidis KT (2018) The Microbial Genomes Atlas (MiGA) webserver: taxonomic 
and gene diversity analysis of Archaea and Bacteria at the whole genome level. Nucleic Acids Res 46:W282-W288

Scheuner C, Tindall BJ, Lu M, Nolan M, Lapidus A, Cheng, J-F, Goodwin L, Pitluck S, Huntemann M, Liolios K (2014) Complete genome sequence of Planctomyces brasiliensis type strain (DSM 5305T), phylogenomic analysis and reclassification of Planctomycetes including the descriptions of Gimesia gen. nov., Planctopirus gen. nov. and Rubinisphaera gen. nov. and emended descriptions of the order Planctomycetales and the family Planctomycetaceae. Stand Gen Sci 9:10

Schlesner H (1989) Planctomyces brasiliensis sp. nov., a halotolerant bacterium from a salt pit. Syst Appl Microbiol 12:159-161

Sievers F, Wilm A, Dineen D, Gibson TJ, Karplus K, Li W, Lopez R, McWilliam H, Remmert M, Söding J (2011) Fast, scalable generation of high-quality protein multiple sequence alignments using Clustal Omega. Mol Syst Biol 7:539

Spring S, Bunk B, Sproer C, Schumann P, Rohde M, Tindall BJ, Klenk HP (2016) Characterization of the first cultured representative of Verrucomicrobia subdivision 5 indicates the proposal of a novel phylum. ISME J 10:2801-2816

Stackebrandt E, Ebers J (2006) Taxonomic parameter revisited: tarnished gold standards. Microbiol Today 33:152-155

Stamatakis A (2014) RAxML version 8: a tool for phylogenetic analysis and post-analysis of large phylogenies. Bioinformatics 30:1312-1313

van Teeseling MC, Mesman RJ, Kuru E, Espaillat A, Cava F, Brun YV, VanNieuwenhze MS, Kartal B, van Niftrik L (2015) Anammox Planctomycetes have a peptidoglycan cell wall. Nat Commun 6:6878

Vollmers J, Frentrup M, Rast P, Jogler C, Kaster AK (2017) Untangling genomes of novel planctomycetal and verrucomicrobial species from Monterey Bay kelp forest metagenomes by refined binning. Front Microbiol 8:472

Wagner M, Horn M (2006) The Planctomycetes, Verrucomicrobia, Chlamydiae and sister phyla comprise a superphylum with biotechnological and medical relevance. Curr Opin Biotechnol 17:241-249

Wiegand S, Jogler M, Jogler C (2018) On the maverick Planctomycetes. FEMS Microbiol Rev 42:739-760

Wiegand S, Jogler M, Boedeker C, Pinto D, Vollmers J, RivasMarín E, Kohn T, Peeters SH, Heuer A, Rast P, Oberbeckmann S, Bunk B, Jeske O, Meyerdierks A, Storesund JE, Kallscheuer N, Lücker S, Lage OM, Pohl T, Merkel BJ, Hornburger P, Müller R-W, Brümmer F, Labrenz M, Spormann AM, Op den Camp HJM, Overmann J, Amann R, Jetten MSM, Mascher T, Medema MH, Devos DP, Kaster A-K, Øvreås L, Rohde M, Galperin MY, Jogler C (2019) Cultivation and functional characterization of 79 planctomycetes uncovers their unique biology. Nat Microbiol. https://doi.org/10.1038/s41564-019-0588-1

Will SE, Henke P, Boedeker C, Huang S, Brinkmann H, Rohde M, Jarek M, Friedl T, Seufert S, Schumacher M (2018) Day and night: metabolic profiles and evolutionary relationships of six axenic non-marine cyanobacteria. Gen Biol Evol 11:270-294

Yarza P, Yilmaz P, Pruesse E, Glöckner FO, Ludwig W, Schleifer KH, Whitman WB, Euzeby J, Amann R, RosselloMora R (2014) Uniting the classification of cultured and uncultured bacteria and archaea using 16S rRNA gene sequences. Nat Rev Microbiol 12:635-645

Publisher's Note Springer Nature remains neutral with regard to jurisdictional claims in published maps and institutional affiliations. 